\title{
Uyarlamalı Sinirsel Bulanık Çıkarım Sisteminin (ANFIS) Talep Tahmini İçin Kullanımı ve Bir Uygulama Onur DOĞAN ${ }^{1}$
}

\author{
$\ddot{O} z$
}

Rekabet unsurunun günümüzde hızla artması, organizasyonların karar problemlerinde rasyonel davranmaları zorunluluğunu da beraberinde getirmiştir. Organizasyonların ve kurumların belirsizlik ve risk ortamında güvenle yol alabilmeleri, karar birimlerinde teknolojiyi ve bilimsel yöntemleri etkin kullanabilmeleri ile mümkündür. Talep tahmini, kurumlardaki kritik karar problemlerinin en başında gelmektedir. Bilimsel yöntemlerle desteklenmiş talep tahmini mekanizmasına sahip bir işletme, tüm fonksiyonlarının verimliliğini ve etkinliğini arttırabilir. Bulanık mantık ve yapay sinir ă̆ları gibi yeni nesil yöntemler işletmeler tarafindan son yıllarda karar verme yöntemi olarak sıklikla kullanılan yöntemler arasındadır. Bu çalışmada işletmeler için kritik bir konu olan talep tahmin problemine ANFIS ile çözüm aranmıştır. Çalışmada önerilen model için öncelikle talebi etkileyen faktörler belirlenmiş ve bu faktörlere ait verilerle modelin veri tabanı oluşturulmuştur. ANFIS yönteminin model talep tahmini için kullanılabileceği gösterilmiştir.

Anahtar Kelimeler: Bulanık Mantık, Talep Tahmini, ANFIS

\section{JEL Sinıflandirma Kodlart: C53, C67 \\ Using Adaptive Neural-Fuzzy Inference Systems (ANFIS) for Demand Forecasting and an Application Abstract}

Due to the rapid increase in global competition among organizations and companies, rational approaches in decision making have become indispensable for organizations in today's world. Establishing a safe and robust path through uncertainties and risks depends on the decision units' ability of using scientific methods as well as technology. Demand forecasting is known to be one of the most critical problems in organizations. A company which supports its demand forecasting mechanism with scientific methodologies could increase its productivity and efficiency in all other functions. New methods, such as fuzzy logic and artificial neural networks are frequently being used as a decision-making mechanism in organizations and companies recently. In this study, it is aimed to solve a critical demand forecasting problem with ANFIS. In the first phase of the study, the factors which impact demand forecasting are determined, and then a database of the model is established using these factors. It has been shown that ANFIS could be used for demand forecasting.

Keywords: Fuzzy Logic, Demand Forecasting, ANFIS

JEL Classification Codes: C53, C67

${ }^{1}$ Öğr. Gör. Dr., Dokuz Eylül Üniversitesi, İzmir Meslek Yüksekokulu, İktisadi ve İdari Programlar, onur.dogan@deu.edu.tr 


\section{O. DOĞAN}

\section{GİRIŞ}

İşletmelerin içerisinde yer aldıkları karar problemleri, genellikle gelecekteki belirsizlikleri ve riskleri tahmin etmeye dayanır. Bir karar problemi içerisinde, karar probleminin yapısı gereği, karar vericinin kontrol edemediği değişkenler mevcuttur. Karar vericiler, bu tip olaylar karşısında etkin kararlar verebilmek için gelişmiş tahmin metotlarına ihtiyaç duyarlar. İşletmelerin ya da organizasyonların daha iyi ürün veya hizmet sunabilmeleri belirsizlik ortamında daha iyi kararlar verebilmeleri ve verilen kararları daha iyi analiz edebilmeleri ile mümkündür. İşletmelerin en önemli problemlerinden biri, ürün veya hizmetlerine olan talebi doğru tahmin edebilmeleridir. Talebin doğru tahmin edilmesi, işletmenin tüm fonksiyonlarını etkileyen önemli bir konudur. Etkin talep tahmini ile, işletmeler; stoklama, promosyon, dağıtım vb. önemli konularda daha doğru kararlar alabilme olanağına sahip olacaklardır. Geleceğin geçmişin bir uzantısı olduğu gerçeği, geleceğe yönelik tahminlerde bulunurken, geçmiş olayların doğru analiz edilmesi zorunluluğunu beraberinde getirir. Geçmiş olayların doğru analiz edilebilmesi ise olaylara yönelik verilerin organizasyonlar tarafından sistemli bir biçimde saklanması ile mümkündür. Sistemli bir biçimde veri depolama yapan bir organizasyon için bir diğer önemli sorun, saklanan bu veriden anlamlı ve kullanılabilir bilgiler üretmektir. İşletmelerde veri yığınları içerisinden kullanılabilir bilgiler üretilmesi bu açıdan önemlidir.

Bu çalışmada, bulanık mantık ve yapay sinir ağlarının birlikte kullanıldığg bir model ile talep tahmini uygulaması yapılmıştır. Çalışmanın doğru parametrelerin belirlenmesi için çok sayıda deneme içermesi ve hızlı gelişen yapay sinir ağ mimarisi içerinde her metot ya da algoritmanın denenmesinin güçlüğü modelin kısıtları arasında sayılabilir. Bu kısıtlara rağmen işletme içerisinde etkin bir bilişim teknolojisi departmanı ve bu departmanın diğer birimlerle etkili iletişimi söz konusu ise model işletmeler için kullanılmaya ve işletmenin ihtiyaçlarına yönelik geliştirilmeye açıktır. 


\section{LITERATÜR TARAMASI}

Yapay sinir ağlarının gerçek hayattaki yaygın uygulama alanlarına; kalite kontrol, finansal öngörü, ekonomik öngörü, kredi derecelendirme, konuşma ve yapı tanımlama, işlem modelleme ve yönetimi, laboratuar araştırmaları, iflas tahmini, petrol ve gaz arama örnekleri verilebilir (Altınöz, 2013: 203).

Literatürde yapay sinir ağlarının geleneksel talep tahmini metotlarına üstünlüğü konusunda birçok çalışma mevcuttur. Ansuj vd. (1996), Chin ve Arthur (1997), çalışmalarında yapay sinir ağlarının talep tahmininde diğer metotlara üstünlüklerini göstermişlerdir. Zhang vd. (1997) o yıla kadar yapılan karşılaştırma çalışmalarının tamamını kendi çalışmalarında ele almışlar ve 23 çalışmanın yalnızca 4 'ünde yapay sinir ağlarının, klasik talep tahmini metotlarından kötü sonuç verdiği sonucuna ulaşılmıştır. Denton (1995), yapay sinir ağlarının diğer modellere üstünlügünü şu şekilde sıralamıştır; "İstatistiksel modellerde karar vericinin değişkenler arasındaki ilişkileri tanımlayan bir fonksiyon yapısını varsayım olarak kabul etmesi gerekir. Yapay sinir ağları bu şekilde bir varsayıma ihtiyaç duymaz, yapay sinir ağlarının değişkenler arası ilişkiyi öğrenebilme yeteneği vardır. Doğrusal regresyon analizlerinde; bağımsız değişkenler arasında korelasyon olmaması, tahmin hatalarının her deneme için bağımsız olması, hataların sabit varyans ve ortalama ile dağılmış olmaları gibi varsayımların yapılması gerekmektedir. Ancak yapay sinir ağlarının değişkenler arasındaki belirsizliğin giderilmesindeki üstünlüğü, herhangi bir varsayıma gereksinim duymadan, modelin ilişkileri öğrenmesine imkân verir. Bunun yanı sıra, talep tahmini öngörüsü için ortaya konan modelde karar vericinin önyargılı veya hatalı bir varsayımı söz konusu iken elde edilen sonuçlar hatalı olabilmektedir. Yapay sinir ağları böyle bir durumdan etkilenmez."

Srinivasan vd. (1994), Lachtermacher ve Fuller (1995) gibi çalışmalar yapay sinir ağlarının, Box-Jenkins (BJ) metotlarından daha iyi sonuçlar verdiğini gösteren çalışmalardandır. Karahan (2011) doktora tezinde yapay sinir ağları ile Malatya ili için kuru kayısı talep miktarını öngörme uygulaması yapmış ve sonuçları BJ metodu sonuçları karşılaştırarak yapay sinir ağlarının daha etkin sonuç 


\section{O. DOĞAN}

verdiği sonucuna ulaşmıştır. Ancak, Maier ve Dandy (1996) kısa dönem tahminlerde BJ metotlarının daha iyi sonuçlar verdiğini göstermişlerdir. Bazı veri kümeleri için ortaya çıkabilen bu handikap nedeniyle yapay sinir ağları ile BJ modellerinin bir arada kullanıldığı hibrid metotların kullanıldığı çok sayıda çalışma söz konusudur. Tseng vd. (2002) BJ ve yapay sinir ağlarının birlikte ve ayrı ayrı kullanıldığı durumlarda elde ettikleri sonuçları karşılaştırmışlardır ve birlikte kullanılan bu metotların, ayrı ayrı kullanıldıkları durumdan daha iyi sonuç verdiğini göstermişlerdir. Aburto ve Weber (2007) ve Khasei (2010) tarafından yapılan, zaman serisinin BJ modeline göre düzenlendiği ve yapay sinir ağı ile birleştirildiği çalışma, hibrid modellere diğer örneklerdir.

Yapay sinir ağlarının yanı sıra bulanık ağ tabanlı yapay siniğ ağları (ANFIS) metodu da talep tahmini için son yıllarda sıklıkla kullanılan bir metottur. Wang vd. (2011) aylık üç farklı modelde otomobil talebini öngörmek için, Azadeh vd. (2009) kısa zamanlı doğal gaz talebini öngörmek için ANFIS metodunu kullanmışlardır. Efendigil (2008) doktora tezinde bir elektronik firmasının yazar kasa talebini öngörmek için, ürün satış fiyatı, ürün kalitesi, müşteri tatmin seviyesi, promosyon ve tatil günleri etkisi değişkenlerini talebi etkileyen faktörler olarak belirlemiş ve ANFIS metodunu kullanmıştır. Efendigil, Önüt ve Kahraman (2009) yapay sinir ağları ile bulanık-yapay sinir ağı modellerinin talep tahmininde kullanımına ilişkin karşılaştırmalı bir çalışma yapmışlardır.

Bunların yanı sıra, yapay sinir ağlarının bazı veriler için kısa dönemli tahminlerdeki zayıflığını gidermek için Thomassey vd. (2003) SAMANFIS metodunu önermişlerdir. Bu metot yapay sinir ağlarının az sayıda veri söz konusu olduğunda ortaya çıkan başarısız sonuçların giderilmesine yöneliktir.

\section{TALEP TAHMINI}

Tekin (1996)' ya göre talep, tüketicilerin bir ürün ya da hizmeti belirli bir fiyat seviyesinden almaya hazır oldukları miktara denir.

Bir ürünün talebini etkileyen, ürünün türü başta olmak üzere birçok faktör bulunmaktadır. Genel anlamda bir malın talebini etkileyen faktörleri malın fiyatı, 
diğer malların fiyatları (ikame mallar-tamamlayıcı mallar), tüketici gelir düzeyi, tüketici serveti ve tüketici zevk ve tercihleri olarak sıralanabilir (Case ve Fair, 1999).

Ürünün mevcut olması durumunda talep aynı zamanda satış anlamına geleceğinden, literatürde talep tahmini yerine satış öngörüsü ifadesi de kullanılmaktadır.

\subsection{Talep Tahmini Yöntemleri}

Talep tahmini yöntemlerini yargısal ve istatistiksel bilginin kullanılmasına göre ayırarak Şekil 1' deki gibi sınıflamak mümkündür; 


\section{O. DOĞAN}

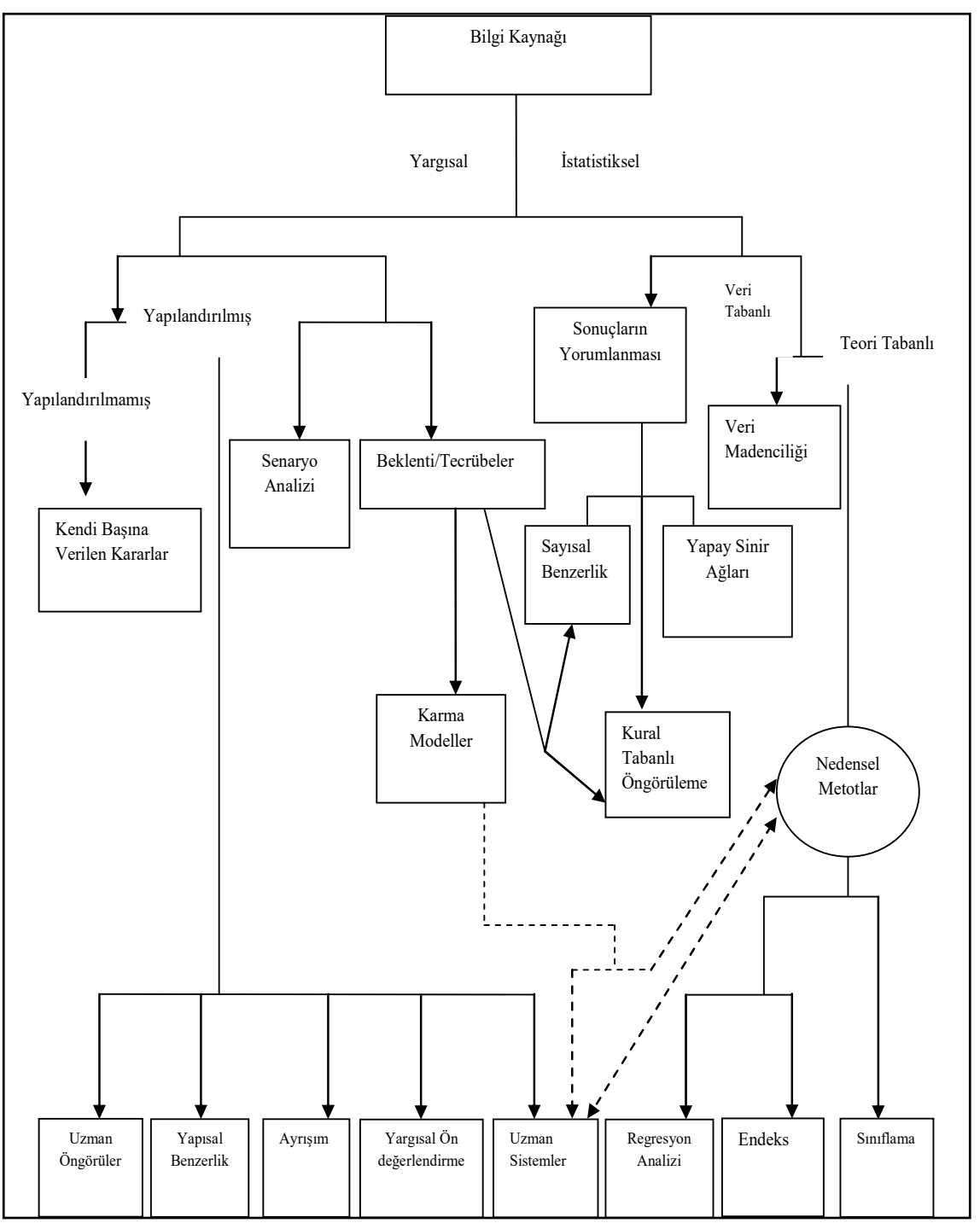

Şekil 1. Tahmin Metotları Ağacı

Kaynak: Amstrong ve Green, 2011: 2.

Talep tahmini yöntemlerini kantitatif ve kalitatif yöntemlerin kullanılmasına göre de sınıflamak mümkündür. Sayısal verilerin kullanılmadığı genellikle uzmanlığın ve tecrübelerin kararda etkin olduğu yöntemler kalitatif yöntemler adı altında incelenebilir. Kalitatif Yöntemleri; Grup Karar Teknikleri, Kilit Personel veya Yönetici Kararı, Satış Gücü Birleşimi, Delphi Yöntemi, Senaryo Analizi gibi 
başlıklar altında sınıflandırmak mümkündür (Heizer ve Render, 2001: 124, Yüksel, 2008: 97).

Geçmiş verileri ve talebi etkileyen faktörleri sayısal olarak ele alarak çıkarım yapmaya yarayan yöntemler ise kantitatif yöntemlerdir. Kantitatif Yöntemler; Ağırlıklı Ortalama Kullanılan Yöntemler, Basit Üssel Düzeltim Yöntemi, Holt Metotları, Box-Jenkins Metotları, Regresyon ve Korelâsyon Analizi gibi başlıkları altında sinıflandırılabilir (Box vd., 2008; Jain ve Malehorn, 2005; Demir ve Gümüşoğlu, 2009; Hoshmand, 2010; Özdemir, 2010).

Hem kalitatif hem kantitatif yöntemler için yeni nesil yöntemlerden bahsetmek mümkündür. Kalitatif yöntemler içerisindeki grup karar teknikleri, teknolojideki hızlı gelişimden etkilenerek teknolojik materyal ve yöntemlerin kullanılmasıyla Yeni Nesil Grup Karar Teknikleri adı verilen tekniklere doğru evrilmiştir.

Kraemer ve King (1988) teknoloji odağında grup karar teknikleri sınıflandırmasını Tablo 1' deki gibi yapmışlardır.

Tablo 1. Grup Karar Tekniklerinin Teknoloji Odaklı Sınıflandırılması

\begin{tabular}{|c|c|c|c|}
\hline $\begin{array}{l}\text { Karar } \\
\text { Tipi }\end{array}$ & Donanım ve Ortam & Yazılım & $\begin{array}{l}\text { Dikkate Alınacak } \\
\text { Konular }\end{array}$ \\
\hline 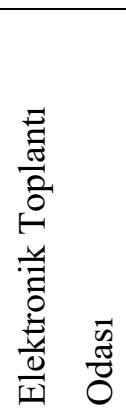 & $\begin{array}{l}\text { Görsel ve işitsel } \\
\text { olanaklı bilgisayar } \\
\text { kontrollü, geniş ekran } \\
\text { projeksiyon imkanı } \\
\text { olan konferans odası }\end{array}$ & $\begin{array}{l}\text { Bilgi depolama ve } \\
\text { sorgulama imkânı } \\
\text { olan uygulamalar }\end{array}$ & $\begin{array}{l}\text { Zaman-mekân } \\
\text { senkronizasyonu } \\
\text { sağlanabilmeli, Görsel- } \\
\text { işitsel unsurları } \\
\text { yönetebilecek teknikler } \\
\text { bulunmalı }\end{array}$ \\
\hline 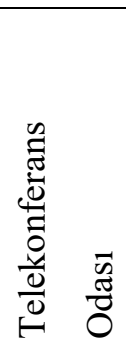 & $\begin{array}{l}\text { Farklı yerler arası } \\
\text { görsel-işitsel iletişimi } \\
\text { sağlayabilecek } \\
\text { bilgisayar kontrolü }\end{array}$ & $\begin{array}{l}\text { Görsel, işitsel ve } \\
\text { belgesel iletişimi } \\
\text { sağlayacak } \\
\text { uygulamalar }\end{array}$ & $\begin{array}{l}\text { Aynı zaman farklı yer } \\
\text { koordinasyonu } \\
\text { sağlanabilmeli, } \\
\text { Konferans teknikeri } \\
\text { mevcut bulunmalı }\end{array}$ \\
\hline
\end{tabular}




\section{O. DOĞAN}

\begin{tabular}{|c|c|c|c|}
\hline 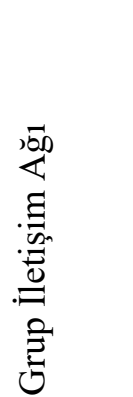 & $\begin{array}{l}\text { Ayrı ofislerde } \\
\text { bağlantıyı } \\
\text { sağlayabilecek } \\
\text { bilgisayar ağı }\end{array}$ & $\begin{array}{l}\text { Masaüstü(desktop) } \\
\text { konferansa izin } \\
\text { veren, Görsel, } \\
\text { işitsel ve belgesel } \\
\text { iletişimi sağlayacak } \\
\text { uygulamalar }\end{array}$ & $\begin{array}{l}\text { Aynı ya da farklı } \\
\text { zaman-mekân } \\
\text { koordinasyonunu } \\
\text { sağlayacak koordinatör } \\
\text { bulunmalı }\end{array}$ \\
\hline 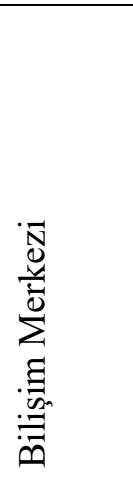 & $\begin{array}{l}\text { Video projektör ve } \\
\text { bireysel } \\
\text { bilgisayarların bağlı } \\
\text { olduğu ortak terminal }\end{array}$ & $\begin{array}{l}\text { İstatistiksel } \\
\text { analizlere, } \\
\text { veritabanı } \\
\text { yönetimine, grafik } \\
\text { ve kelime } \\
\text { işlemlerine izin } \\
\text { veren uygulamalar }\end{array}$ & $\begin{array}{l}\text { Zaman-mekân } \\
\text { koordinasyonu } \\
\text { sağlanmalı, } \\
\text { Uygulamaları } \\
\text { yönetebilecek uzman } \\
\text { bulunmalı }\end{array}$ \\
\hline 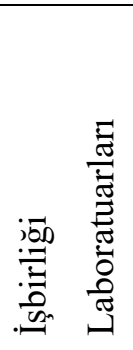 & $\begin{array}{l}\text { A ğ bağlantılı } \\
\text { bilgisayarlar, } \\
\text { elektronik tahta }\end{array}$ & $\begin{array}{l}\text { Bilgi değişimine } \\
\text { imkân sağlayan } \\
\text { uygulamalar }\end{array}$ & $\begin{array}{l}\text { Aynı ya da farklı } \\
\text { zaman koordinasyonu } \\
\text { ve grup karar } \\
\text { tekniklerini } \\
\text { işletebilecek uzman }\end{array}$ \\
\hline 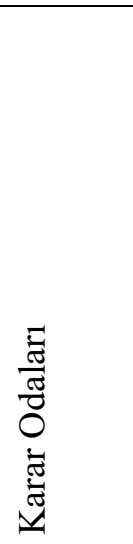 & $\begin{array}{l}\text { Görsel ve işitsel } \\
\text { olanaklı bilgisayar } \\
\text { kontrollü, geniş ekran } \\
\text { projeksiyon imkanı } \\
\text { olan konferans odası }\end{array}$ & $\begin{array}{l}\text { Modelleme imkânı } \\
\text { tanıyan, karar } \\
\text { analizi yapabilen, } \\
\text { beyin firtınası, } \\
\text { Delphi metot vb. } \\
\text { tekniklerin } \\
\text { yapılabildiği } \\
\text { uygulamalar }\end{array}$ & $\begin{array}{l}\text { Aynı ya da farklı } \\
\text { zaman koordinasyonu } \\
\text { ve grup karar } \\
\text { tekniklerini } \\
\text { işletebilecek uzman }\end{array}$ \\
\hline
\end{tabular}

Kaynak: Kraemer ve King, 1988: 120.

Teknolojinin etkin olarak kullanıldığ grup karar teknikleri için grup yazılımı (groupware) terimi ortaya atılmıştır. $\mathrm{Bu}$ yazılımlarda bir organizasyonunun 
geçmişinden bugüne tüm verileri kullanılabilir olarak saklanmalıdır. Grup yazılım yapısında organizasyondaki araçlar, kişiler, kurallar, prosedürler, bültenler, planlama panoları, ağdaki diğer bilgisayarlar bilgisayar tabanlı olarak yer almaktadır (Marakas, 2003: 160).

Yeni Nesil Yöntemler arasında ise yapay sinir ağları ve bulanık mantık yöntemleri sayılabilir.

\section{BULANIK MANTIK VE YAPAY SİNIR AĞLARI}

Bulanık mantık ve yapay sinir ağlarını çatısı altına alan, yapay zekâ kavramının birçok tanımı yapılabilir. Genel olarak yapay zekâ, insan zekâsının makineler üzerinde simülasyonu olarak tanımlanabilir. Bir makinenin yapay zekâya sahip olması, bir problemi tanımlayabilmesi, problemin uygun adımında uygun bilgiyi kullanabilmesi anlamına gelmektedir (Konar, 2000: 3).

\subsection{Bulanık Mantık ve Bulanık Mantık Kavramları}

Klasik mantık kavramının temelinde bir önermenin doğru ya da yanlış olabileceği, üçüncünün olmazlığı ilkesi vardır. Bu sistem, Aristoteles Mantığı, Klasik Mantık, İkili Mantık gibi adlarla adlandırılmaktadır. Bu iki değerli mantık değer kümesi $\{0,1\}$ ile ifade edilmektedir. 0 ifadesi önermenin yanlışlı̆̆ını, 1 ise doğruluğunu ifade etmektedir. $\mathrm{Bu}$ durum bugünkü bilgisayar sistemlerinin de temelini oluşturmaktadır (ikili-binary- sistem). Ancak bulanık mantık kavramının temelinde bu kesin sinırlar yerine kümelere dereceli aidiyetler ilkesi vardır. Bulanık mantık ise; 0 ile 1, doğru ile yanlış, vb. karşıt ifadeler arasında bir geçiş önermektedir. Bu durum ikili mantık yerine bazı olayların çok değerli mantık ile ele alınmasını gerekli kılmaktadır. 1965 yılında Zadeh ise çok değerli mantık değer kümesini $[0,1]$ aralığında tanımlamış ve ortaya koyduğu teorinin adını Bulanık Mantık Teorisi olarak isimlendirmiştir.

\section{Bulanık Küme Kavramı}

Klasik küme kavramında bir eleman bir kümeye aittir ya da değildir. $\mathrm{Bu}$ fonksiyon $\mu_{A}: X \rightarrow\{0,1\}$ biçimde ifade edilir. Bulanık kümelerde ise bir elemanın kümeye ait olma durumu üyelik dereceleri ile ifade edilir. Bir bulanık küme 


\section{O. DOĞAN}

içerisinde bir elemanın kümeye aitlik derecesi, her elaman için $[0,1]$ aralığına işaret eden $\mu_{A}: X \rightarrow[0,1]$ biçiminde bir üyelik fonksiyonu ile ifade edilir. Bu haliyle klasik kümeler ile karşılaştırıldığında bulanık kümelerin, sınırları belirsiz kümeler olduğu tanımlaması yapılabilir (Lee, 2005: 7).

Bir bulanık küme, $\mu_{A}(x), \mathrm{X}$ elemanının bulanık kümeye üyelik derecesini göstermek üzere, aşağıdaki biçiminde gösterilir:

$$
\begin{aligned}
& A=\left\{\mu_{A}(x) / x \in X, \mu_{A}(x) \in[0,1] \in R\right\} \\
& A=\left\{x_{1}, x_{2}, x_{3}, \ldots, x_{n}\right\} \\
& A=\left\{\mu_{A}\left(x_{1}\right) / x_{1}+\mu_{A}\left(x_{2}\right) / x_{2}+\ldots+\mu_{A}\left(x_{n}\right) / x_{n}\right\}
\end{aligned}
$$

Son eşitlik $A=\left\{\sum \mu_{A}\left(x_{i}\right) / x_{i}\right\}$ biçiminde, bulanık kümenin sürekli olması durumunda ise, $A=\left\{\int \mu_{A}\left(x_{i}\right) / x_{i}\right\}$ biçiminde gösterilir. $\int$ ve $\sum$ işaretleri klasik anlamlarını değil, elemanların topluluğunu ifade eden anlamda kullanılır (Galindo, Urrutia, \& Piattini, 2005: 3).

\section{Dilsel Değişken Kavramı}

Genel olarak değişkenler sayısal değerler alırlar. Eğer bir değişkene dilsel terim atanırsa dilsel değişken adını alır. X; değişken adı, T(x); değişkene değer olabilecek sözel terim kümesi, E; değişken karakteristiklerini tanımlayan evrensel küme, G; T(X)' de terim üreten dizimsel gramer ve $M$; E' deki bulanık kümelere karşılık gelen $\mathrm{T}(\mathrm{X})$ terimlerinin semantik kuralları olmak üzere Baykal ve Beyan (2004a) sözel değişken şu şekilde tanımlamışlardır;

Dilsel Değişken $=(X, T(X), E, G, M)$

Örneğin, "yaş" sözel değişkenini ele alınsın,

Yaş: X değişkeninin adı

$\mathrm{T}(\mathrm{X})$ : $\{$ genç, çok genç, çok çok genç, ...

E:[0,100] evrensel küme

$\mathrm{G}(\mathrm{X}): \mathrm{T}^{\mathrm{i}+1}=\{$ genç $\} \cup\left\{\right.$ çok $\left.\mathrm{T}^{\mathrm{i}}\right\}$ 


$$
\begin{aligned}
& \mathrm{M}(\mathrm{genç})=\left\{\left(\mathrm{e}, \mu_{\mathrm{genç}}(\mathrm{e})\right), \mathrm{e} \in[0,100]\right\} \\
& \mu_{\mathrm{genç}}(\mathrm{e})=\left\{\begin{array}{c}
e \in[0,25] \text { ise } 1 \\
e \in[25,100] \text { ise }\left(1+\frac{e-25}{5}\right)^{-2}
\end{array}\right.
\end{aligned}
$$

Dilsel değişkenden üyelik fonksiyonları ile yeni dilsel değişkenler türetilebilir. Örneğin; "Öğrencilerin çoğu lisans öğrencisidir" ve "Lisans öğrencilerinin çoğu gençtir" yargıları birleştirilerek "Öğrencilerin (çoğu) $)^{2}$ 'si gençtir” yargısına ulaşılabilir. Burada ikinci üyelik fonksiyonu ilk üyelik fonksiyonun karesi alınarak üretilmiştir (Zadeh, 1988)².

\section{Üyelik Fonksiyonları}

Bir kümenin elemanlarının kümeye aitlik derecesini gösteren fonksiyonlar üyelik fonksiyonları olarak adlandırılırlar.

Örneğin; bir bulanık A kümesi, " $\mathrm{A}=\{0$ 'a yakın reel sayılar $\}$ " olarak tanımlansın, üyelik fonksiyonu $\mu_{A}(x)=\frac{1}{1+x^{2}}$ olduğu durumda 0 sayısı A kümesinin tam olarak bir elemanıdır ve üyelik derecesi 1'dir. Ancak 1 sayısının 0' a yakın reel sayılar kümesine üyelik derecesi, tanımlanan üyelik fonksiyonu kullanılarak 0,5 olarak bulunur $\left(\mu_{A}(0)=\frac{1}{1+0^{2}}=1, \mu_{A}(1)=\frac{1}{1+1^{2}}=0,5\right)$.

Bazı üyelik fonksiyonları; üçgen üyelik fonksiyonu, yamuk üyelik fonksiyonu, gauss üyelik fonksiyonu, çan şekilli üyelik fonksiyonu, sigmoidal üyelik fonksiyonu, s üyelik fonksiyonu olarak sıralanabilir.

\section{Bulanık Kurallar ve Bulanık Çıkarım}

Bir bulanık model içerisinde bulanıklaştırma, kural tabanlarının oluşturulması, değerlendirilmesi ve toplanması, berraklaştırma, işlemleri sırasıyla birbirini takip eder. Jang (1993), bulanık sistem sürecini Şekil 2'deki gibi modellemiştir

\footnotetext{
${ }^{2}$ Orijinal metinde "most" ve "most ${ }^{2}$ " ifadeleri kullanılmıştır.
} 


\section{O. DOĞAN}

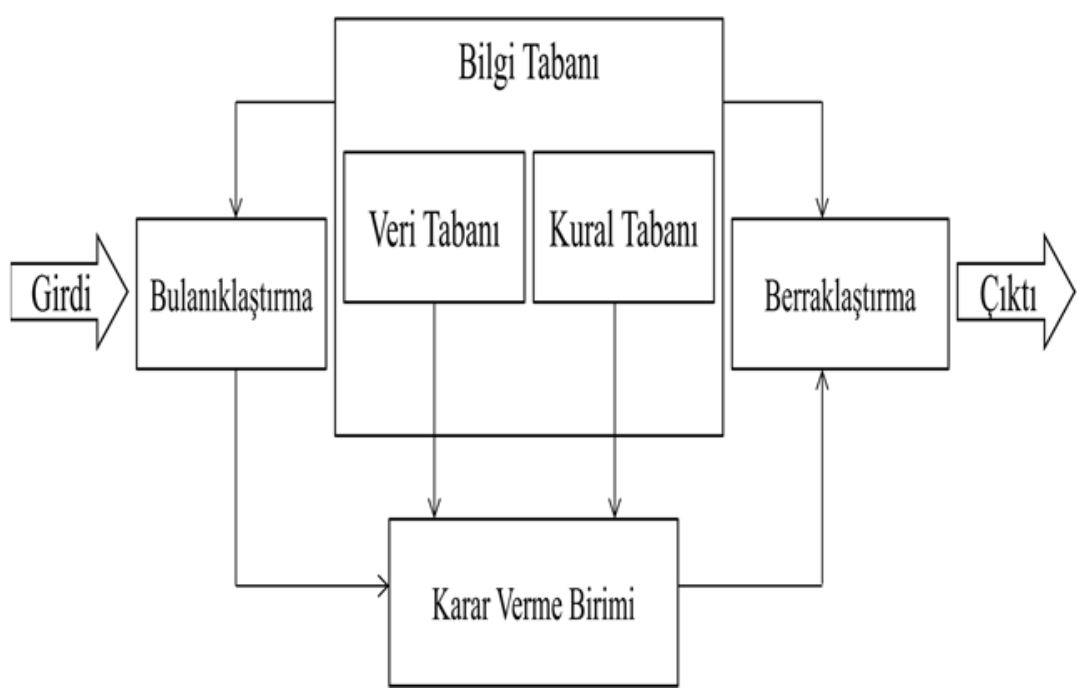

Şekil 2. Bulanık Çıkarım Sistemi

Bulanıklaştırma işlemi bulanık mantık ile modellemenin ilk adımıdır. Bu adımda modelin girdi ve çıktı değerleri daha önceden belirtilen üyelik fonksiyonundan biri ile [0,1] aralığında üyelik derecesini belirten bir değere çevrilerek bulanıklaştırılır. Kural tabanının oluşturulması, değerlendirilmesi ve toplanması adımlarının başlangıcını bulanık kural tanımlama aşaması oluşturur. $\mathrm{Bu}$ aşamada EĞER-İSE ifadeleri ile kavramsal terimler birbiri ile ilişkilendirilir. Birden çok girdi söz konusu ise VE-VEYA işlemcileri ile bu girdiler birbirine bağlanır.

Bulanık kümeleri, $\mathrm{A}_{\mathrm{i}}$ ifadeleri bulanık kümeleri tanımlamak üzere, EĞER-İSE kurallarıyla VE-VEYA operatörleri ile birleştirilirse, ilişki aşağıdaki gibi kurulabilir (Passino ve Yurkovich, 1998: 55);

"EĞER, $A_{1}$ VE $A_{2}$ VE $\ldots . .$. VE $A_{n}$ İSE $B_{i}$ "

Bulanık kurallar, bulanık çıkarım sistemlerinin temelini oluştururlar. Yapıları itibariyle bulanık belirsiz ortamlarda insan düşünce ve muhakeme yeteneğini yansıtma kabiliyeti taşırlar. Örneğin; "Eğer fiyat yüksek ise talep düşüktür" kuralını incelersek burada fiyat ve talep dilsel değişkenler, yüksek ve düşük ise ilgili değerlere karşılık gelen değerlerdir (Yücel, 2010: 35). 
Oluşturulan kurallar içerisinden muhakeme yapılarak sonuç değeri oluşturulması işlemi "çıkarım” olarak tanımlanır. En çok kullanılan çıkarım yöntemleri Mamdani Yöntemi ve Takagi-Sugeno-Kang Yöntemleridir. Bunların dışında Larsen Yöntemi ve Tsukamoto Yöntemi kullanılan diğer çıkarım yöntemleri arasında sayılabilir. Çıkarım kümelerinin bir araya getirilerek tek bir küme olarak ifade edilmesi ise kural toplama olarak adlandırılır (Baykal ve Beyan, 2004a).

Bulanık bir modelin son aşaması berraklaştırma, yani bulanıklaştırılan değerlerin tekrar net hale dönüştürülmesi aşamasıdır. Berraklaştırma işlemi literatürde durulama ya da netleştirme ifadeleri ile de anılmaktadır. Literatürde kullanılan bazı berraklaştırma metotları; En Büyük Üyelik Metodu, Ağırlık Merkezi Metodu, Ortalama Ağırlık Metodu, En Büyüklerin Ortalaması Metodu, Alanı İkiye Bölen Nokta Metodu olarak sıralanabilir.

\subsection{Bulanık Mantık ve Sinir Ağları Entegrasyonu}

Yapay sinir ağları, insan beyninin özelliklerinden olan, öğrenme yolu ile yeni bilgiler türetebilme, yeni bilgiler oluşturabilme ve keşfedebilme gibi yetenekleri herhangi bir yardım almadan otomatik olarak gerçekleştirmek amacıyla geliştirilen bilgisayar sistemleridir. Yapay sinir ağları insan beyninin fonksiyonel özelliklerine benzer biçimde; öğrenme, ilişkilendirme, sınıflandırma, genelleme, özellik belirleme, optimizasyon gibi konularda başarılı bir şekilde uygulanmaktadır (Öztemel, 2012: 29).

Yapay sinir hücreleri; öğrenme ve uygulama olarak iki işleme sahiptirler. Yapay sinir hücreleri mevcut geçmiş verilerde tanımlanmış girdi ve çıktılar arasındaki ilişkiyi öğrenmesi konusunda eğitilir. Bu eğitim yapay sinir hücresinin öğrenebilme fonksiyonu ile ilintilidir. Güncel girdiler ile öğrendiği yapı üzerinden çıktı tanımlaması ise hücrenin uygulama fonksiyonu ile alakalıdır.

Yapay öğrenme bilgisayarların örnek veri ya da geçmiş deneyimi kullanarak başarımlarını attıracak biçimde programlanmasıdır. Analiz için, parametrelere bağlı olarak tanımlanmış bir model ve modelin başarımını ölçmek için kullanılabilecek 


\section{O. DOĞAN}

bir ölçüt tanımlı olmalıdır. Amaç, modelin parametrelerini bu başarım ölçütüne göre en iyi yapan parametre değerlerini bulmaktır. Model, gelecekte ilgili öngörüler yapmak için yapmak için kullanılacak bir öngörücü ya da bilgi çıkarmaya yarayan açıklayıcı bir model olabilir (Alpaydın, 2011:3).

Yapay öğrenme kuralları danışmanlı öğrenme, danışmansız öğrenme ve pekiştirerek öğrenme olmak üzere üç sınıfa ayrılabilir. Danışmanlı öğrenme kuralları, arzu edilen ağ çıkışının elde edilebilmesi için, çıkış hatasının düşürülmesinde ağırlıkların uyarlanabilir hale getirilmesini gerektirir. Bu öğrenme tipinde her giriş değeri ile birlikte çıkış değeri de sisteme tanıtılır. Danışmansız ya da pekiştirerek öğrenme kurallarında istenilen çıtı değeri sisteme tanıtılmaz (Elmas, 2011: 42).

Bir ağın öğrenmesinin gösterilmesinin en güzel yolu hata grafiğini çizmektir. Öğrenen bir ağ için her iterasyonda oluşan hatanın grafiği çizilirse Şekil 3’tekine benzeyen bir hata grafiği oluşur.

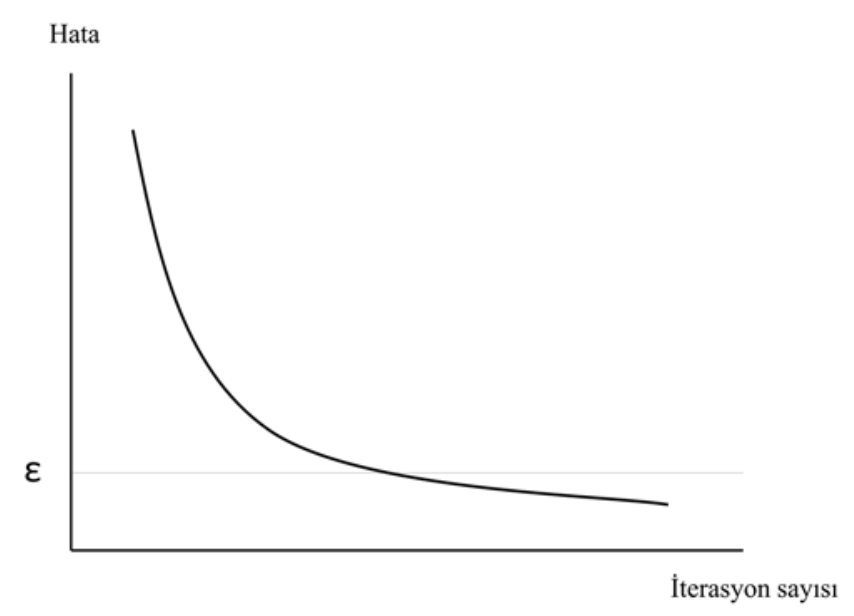

\section{Şekil 3. Örnek Bir Öğrenme Eğrisi}

Belirli bir iterasyondan sonra hatanın daha fazla azalmadığı görülmektedir. $\mathrm{Bu}$ ağın öğrenmesinin durduğu ve daha iyi bir sonuç bulamayacağı anlamına gelir (Öztemel, 2012: 85). 
Dokuz Eylül Üniversitesi İktisadi ve İdari Bilimler Fakültesi Dergisi Cilt:31, Sayl:1, Yll:2016, ss. 257-288

Sinir ağları ve bulanık mantık teknolojileri birbirlerini tamamlayan iki teknolojidir. Sinir ağları veriden öğrenebilir, fakat sinir ağları ile öğrenilen bilgiyi anlamak zordur. Tersine bulanık sistemler sözel terimler ve eğer-ise kuralları kullandıkları için kolayca anlaşılabilir ancak öğrenme algoritmaları yoktur. Birbirini tamamlayan bu tekniklerin özellikleri Tablo 2 'de gösterilmiştir (Baykal ve Beyan, 2004b: 425).

Tablo 2. Bulanık Sistemler ve Sinir Ağlarının Özellikleri

\begin{tabular}{|l|l|l|l|}
\hline \multicolumn{2}{|c|}{ Yetenekler } & $\begin{array}{l}\text { Bulanık } \\
\text { Sistemler }\end{array}$ & Sinir Ăgları \\
\hline \multirow{3}{*}{ Bilgi Edinimi } & Girdiler & $\begin{array}{l}\text { İnsan } \\
\text { Uzmanlar }\end{array}$ & Örnek Kümeler \\
\cline { 2 - 4 } & Araçlar & Etkileşim & Algoritmalar \\
\hline \multirow{3}{*}{ Belirsizlik } & Bilgi & Nicel ve Nitel & Nicel \\
\cline { 2 - 4 } & Bilişsellik & Karar Verme & Alg1 \\
\hline \multirow{3}{*}{ Akıl Yürütme } & Mekanizma & $\begin{array}{l}\text { Deneyimsel } \\
\text { Araştırma }\end{array}$ & Paralel Bilgiişlem \\
\cline { 2 - 4 } & Hiz & Düşük & Yüksek \\
\hline \multirow{3}{*}{ Uyarlanma } & Hata Toleransı & Düşük & Çok yüksek \\
\cline { 2 - 4 } & Öğrenme & İndüksiyon & $\begin{array}{l}\text { Ayarlanmış } \\
\text { Ağırlıklar }\end{array}$ \\
\hline \multirow{2}{*}{ Doğal Dil } & Gerçekleştirme & Açık & Gizli \\
\cline { 2 - 4 } & Esneklik & Yüksek & Düşük \\
\hline
\end{tabular}

Kaynak: Baykal ve Beyan, 2004b: 425.

Beyan ve Baykal (2004b)'a göre bulanık mantık ve yapay sinir ağlarının sentezinde beş farklı kategoriden bahsetmek mümkündür. Bunlar; bulanıklı̆ğ sinir ağı çatısına sokmak, bulanık mantık biçimselliği ile sinir ağı tasarlamak, sinir 


\section{O. DOĞAN}

hücrelerinin temel özelliklerini değiştirmek, bir ağın kararsızlığı ya da hatası olarak bulanıklık ölçümünün kullanmak, her bir sinir hücresini bulanık yapmak olarak siralanabilir.

Bulanık mantık ve yapay sinir ağlarının entegre kullanıldığı hibrid sistemlerin çoğu, bulanıklı̆̆g sinir ağı çatısına sokmak ve sinir hücrelerinin temel özelliklerini değiştirmek kategorilerindeki ilkelerle yapılmaktadır. Literatürde birçok bulanık sinir hücresi (VEYA bulanık sinir hücresi, Kwan-Cai bulanık sinir hücresi, vb.) ve çok sayıda bulanık sinir ağı tipi (Yawaka bulanık sinir ağı, Kwak, Lee ve LeeKwang bulanık sinir modeli vb.) vardır. Bunun yanı sıra kullanılan diğer sinirsel bulanık sistemler; ANFIS, FALCON, FuNe, RuleNet, GARIC, NEFCLASS, NEFCON, NEFPROX şeklinde sıralanabilir. Çalışmada; talep tahmini yapılırken ANFIS (Adaptive Neural Fuzzy Inference System) metodu kullanılacaktır.

\subsection{Sinirsel Bulanık Mantık Çıkarım Sistemi (ANFIS)}

ANFIS metodunun temelinde bulanık çıarım sistemlerinde Takagi-SugenoKang bulanık çıkarım sistemi vardır.

Jang (1993) ANFIS yöntemini geliştirmiş ve doğrusal olmayan fonksiyonların modellenmesinde, kontrol sisteminde doğrusal olmayan bileşenlerin belirlenmesinde ve kaotik zaman serilerinin tahmininde kullanmıştır. Ayrıca yöntemi MATLAB yazılımındaki Bulanık Mantık Modülü’nde bir Kullanıcı Arayüzü (GUI) aracıllğı ile kullanıma sunmuştur (Yücel, 2010: 35).

ANFIS yapısı aşağıdaki Şekil 4'te gösterilebilir (Jang, 1993). 


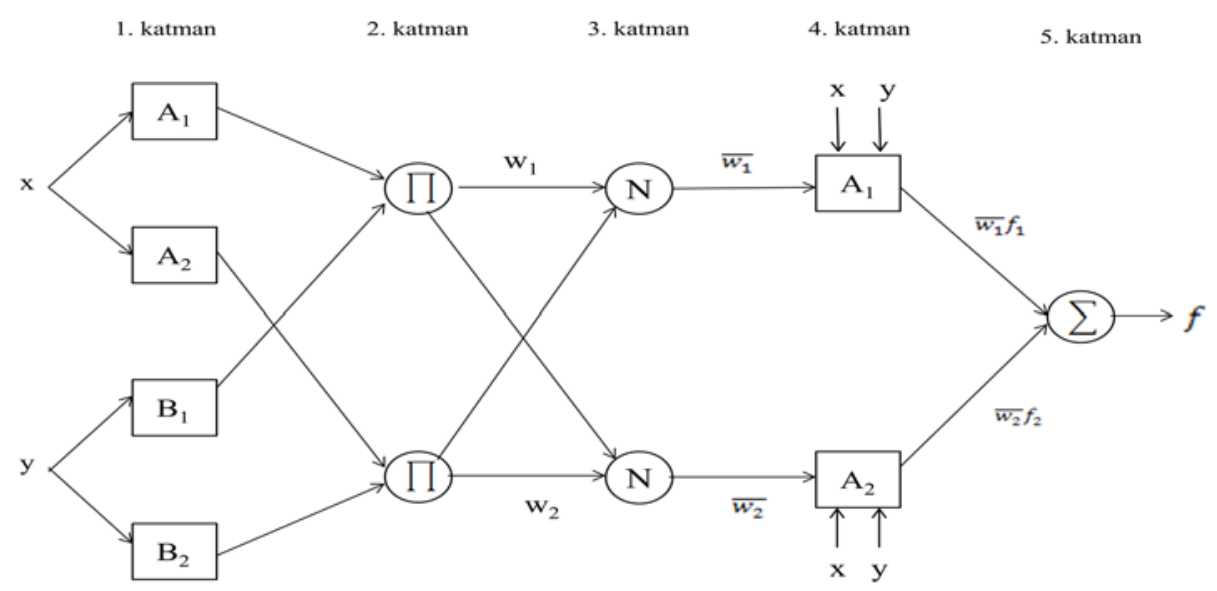

Şekil 3. ANFIS Modeli

Kaynak: Jang, 1993: 668.

$\mathrm{Bu}$ modelde birinci katmanda, $\mathrm{A}_{i}$ ve $\mathrm{B}_{\mathrm{i}}$ değerleri sözel değişkenleri ifade etmek için kullanılır. $A_{i}$ ve $B_{i}$ değerleri bir üyelik fonksiyonu vasıtasıyla, üyelik derecelerini alarak katmandan çıkarlar. 2. katmanda ise girdiler çarpılarak bir düğümden çıkarlar. Üçüncü katmanda ateşleme gücü değerleri toplam ateşleme gücü değerlerine oranlanarak normalize edilir. Dördüncü katmandan sonra, TakagiSugeno-Kang modeli işletilir. Takagi-Sugeno-Kang (TSK) Çıkarım Yöntemi’nde çıkış değişkeni sabit bir sayı ya da değişkene bağlı polinom fonksiyon olarak tanımlanmaktadır (Şen, 2004: 130).

TSK Modelinde çıkış değeri ortalama ağırlık modeli ile hesaplanır (Babuska, 2001: 48);

$$
x_{0}=\frac{\sum \alpha_{i} \cdot x_{i}}{\sum \alpha_{i}}
$$

Ayrıca, TSK yöntemi çıktı değerleri berrak değerlerdir. Bu yöntem ile çıkarım yapılmışsa tekrar berraklaştırma işlemine gerek yoktur.

Beşinci katman sonucunda toplam çıktı değeri modelden elde edilir.

Süreç aşağıdaki gibi özetlenebilir;

Kural kümesi: EĞER, $x A_{i}$ VE y $B_{i} \quad$ İSE $f_{i}=p_{i} \cdot x+q_{i} \cdot y+r_{i}$ 


\section{O. DOĞAN}

1. Katman: Bir üyelik fonksiyonu $(\mu(x))$ seçilerek sözel değişkenlerin üyelik dereleri belirlenir. $\left(\mu_{A_{i}}(x), \mu_{B_{i}}(y)\right)$

2. Katman: $w_{i}=\mu_{A_{i}}(x) \cdot \mu_{B_{i}}(y)$

3. Katman: $\overline{w_{l}}=\frac{w_{i}}{\sum w_{i}}$

4. Katman: $\overline{w_{l}} . f_{i} \quad$ katman çıktısıdır.

5. Katman: $x_{0}=\frac{\sum w_{i} \cdot f_{i}}{\sum w_{i}}$

\section{UYGULAMA}

Çalışmanın uygulama bölümünde Türkiye'de 15 farklı şubede faaliyet gösteren bir cash\&carry firmasının bir şubesine ait haftalık talep miktarı öngörüsü yapılacaktır. Talep tahmini yapılacak ürün Selpak 16'lı tuvalet kâğıdı olarak belirlenmiştir. Stok yöneticisi ile yapılan görüşme ile bu ürünün talebini etkileyen faktörler; ürünün firmaya maliyeti, ürünün fiyat1, rakip ürünün fiyatı (Familya 16'lı tuvalet kâğıdı) ve enflasyon oranı olarak belirlenmiştir. Çalışmada 2009-2011 yılları arasını kapsayan 155 haftalık veri seti kullanılmıştır.

Çalışmada analizler için Matlab yazılımı kullanılmıştır. Matlab yazılımı, MathWorks firması tarafından geliştirilmiş, teknik hesaplama dili ve ortamı olarak kullanılabilen, içerisinde birçok yardımcı araç ve yazılım olan, günümüzün popüler teknik uygulama yazilımlarından birisidir (MathWorks, 2002) ${ }^{3}$.

\subsection{Veri Setinin Hazırlanması}

Veri setinin oluşturulması sürecinde; veriler normalize edilmiş, öğretim ve test setleri oluşturulmuş ve girdilerin belirlenmesi işlemleri yapılmıştır.

\footnotetext{
${ }^{3}$ Matlab programındaki anfis editor ile ilgili detaylı bilgi için bkz. Fuzzy Logic ToolboxUser's Guide: http://cn.mathworks.com/help/pdf_doc/fuzzy/fuzzy.pdf. Ayrıca, Tedarikçi Seçimi Probleminde Bütünleşik Sinirsel Bulanık Mantık Yaklaşımı (Atakan Yücel) isimli doktora tezi Matlab programının ara yüzleri ve işlevlerini detaylı açıklayan bir çalışmadır.
} 
Uygulamada da kullanılacak veritabanı oluşturulurken veriler [0,1] aralığına lineer transformasyon yöntemi ile normalize edilmiştir (Zhang vd., 1998: 49):

$$
x_{n}=\frac{x_{0}-x_{\min }}{x_{\operatorname{maks}}-x_{\min }}
$$

155 kayıtlık veri içerisinden ANFIS ve yapay sinir ağları metotlarının doğası gereği ihtiyaç duydukları öğretim seti ve test seti oluşturulmuştur. Veri setinin öğretim ve test olmak üzere iki parçaya ayrılması için basit rastsal ayrım yöntemi kullanılmıştır (Mitchell, 1997). Bu yönteme göre bütün veri setinin yaklaşık 2/3 'lük kısmı öğretim kümesi olarak belirlenmiştir. Veri seti zaman sırasında iken, talep tahminin yapılacağı modelde veri kümesi üzerinde yapılan pilot çalışmalarda başarısız sonuçlar vermiştir. Bu nedenle veri kümesinden rastsal olarak öğretim seti seçilmiştir. Buna göre, 105 veri ile öğretim yapılacak, 50 veri ile öğrenilen yapının doğruluğu test edilecektir.

Modelin performans değerlendirme ölçütü olarak hata karelerinin ortalamasının kökü (RMSE) değeri kullanılmıştır (Witten vd., 2011: 180);

$$
R M S E=\sqrt{\frac{\left(p_{1}-a_{1}\right)^{2}+\cdots+\left(p_{n}-a_{n}\right)^{2}}{n}}
$$

Literatürde yer alan birçok uygulamanın yanı sıra yöntemi geliştiren Jang'ın da ortaya koyduğu üzere ANFIS yöntemi az girdi ile etkin bir çözüm ortaya koymaktadır (Yücel, 2010: 81). Bu nedenle girdi sayısının azaltılması daha az hata ile öngörü yapabilme imkânı verebilir. ${ }^{4} \mathrm{Bu}$ nedenle girdi sayısı üçe indirilerek çözüm yapılmıştır. Girdi belirleme aşamasında mevcut girdiler arasından hangi üçünün seçileceği de kritik bir karardır. Dört değişken arasından bağımlı değişkene en çok etki eden üç girdinin belirlenmesi için, oluşan her üç girdi ayrı ayrı modele sokulmuştur. Bu yapı itibariyle dördün üçlü kombinasyonundan dört farklı durum ortaya çıkmıştır. Dört farklı durumun RMSE değerlerleri üzerinden değerlendirme yapılarak en iyi üçlü model için seçilmiştir. Eğitim ve test verisinin RMSE değerleri Tablo 3'te belirtilen biçimde bulunmuştur. Familya fiyat, Selpak fiyat ve

${ }^{4}$ İlerleyen bölümde 3 girdili ve 4 girdili modellere ilişkin performans ölçütleri toplu biçimde verilmiştir. 


\section{O. DOĞAN}

Selpak maliyet değişkenleri diğer üçlü değişkenlerle karşılaştırıldığında, eğitim RMSE değeri=0,1041 ve test RMSE değeri=1,4169 ile en uygun girdi kümesi olarak tespit edilmiştir.

Tablo 3. Üç Girdili Modeller Performans Testi Sonuçları

\begin{tabular}{|l|l|l|l|}
\hline $\begin{array}{l}\text { Model } \\
\text { No }\end{array}$ & Girdiler Hŏitim Hata & $\begin{array}{l}\text { Test Hata } \\
\text { Değeri }\end{array}$ \\
\hline 1 & $\begin{array}{l}\text { Familya Fiyat / Selpak Fiyat / Selpak } \\
\text { Maliyet }\end{array}$ & 0,1041 & 1,4169 \\
\hline 2 & $\begin{array}{l}\text { Familya Fiyat / Selpak Fiyat / Enflasyon } \\
\text { Oranı }\end{array}$ & 0,0932 & 1,7042 \\
\hline 3 & $\begin{array}{l}\text { Familya Fiyat / Selpak Maliyet / } \\
\text { Enflasyon Oran1 } 0,0987\end{array}$ & 15,1827 \\
\hline 4 & $\begin{array}{l}\text { Selpak Fiyat / Selpak Maliyet / } \\
\text { Enflasyon Oran1 } 0,0929\end{array}$ & 2,1207 \\
\hline
\end{tabular}

Tablo 3'e göre; 1,4169 test değeri ile diğer üçlü grupların test değerlerinden düşük olan Familya Fiyat, Selpak Fiyat ve Selpak Maliyet üçlü grubu en az hata değerine sahip gruptur.

\subsection{ANFIS Tahmin Modelinin Kurulması ve Test Edilmesi}

Veri seti hazırlandıktan ve ögretim-test veri sayıları belirlendikten sonra talep öngörüsü yapılmadan önce modele ait bir takım faktörlerin belirlenmesi işlemi yapılmalıdır. Belirlenmesi gereken diğer öğeler kullanılacak dilsel değişken sayısı, kullanılacak üyelik fonksiyonu tipi, bulanık çıkarım derecesi, optimizasyon metodu, hata toleransı, eğitim çevrim sayısı şeklinde sıralanabilir.

Kullanılacak üyelik fonksiyonu seçilirken, her bir üyelik fonksiyonu için ayrı ayrı denenerek ve çözümler arası karşılaştırma yapılarak optimal fonksiyon seçilebilir. 
Çalışmada girdilere ait iki dilsel değişken seçilmiştir. Familya fiyat, selpak fiyat, selpak maliyet değerleri için "düşük” ve “yüksek" dilsel değişkenleri belirlenmiştir. TSK çıkarım modeli olarak birinci derece seçilmiştir. Kullanılacak üyelik fonksiyonunu belirlemek için bütün üyelik fonksiyonları ayrı ayrı eğitilerek denenmiştir. Eğitim sonucu oluşan 50 çevirimlik (ön tanımlı değer) hata değerleri Tablo 4'te gösterildiği gibidir.

Tablo 4. Üyelik Fonksiyonları Hata Değerleri

\begin{tabular}{|l|l|l|}
\hline Üyelik Fonksiyonu & $\begin{array}{l}\text { Matlab İsim } \\
\text { Kodu }\end{array}$ & Hata Değeri \\
\hline Üçgen Üyelik Fonksiyonu & trimf & 0,14176 \\
\hline Yamuk Üyelik Fonskiyonu & trapmf & 0,14584 \\
\hline Çan Şekilli Üyelik Fonskiyonu & gbellmf & 0,14172 \\
\hline Gauss Üyelik Fonksiyonu(tam simetrik) & gaussmf & 0,14172 \\
\hline Gauss Üyelik Fonksiyonu & gauss2mf & 0,14172 \\
\hline П Üyelik Fonksiyonu & pimf & 0,14196 \\
\hline Sigmodial Üyelik Fonksiyonu(tam simetrik) & dsigmf & 0,14196 \\
\hline Sigmodial Üyelik Fonksiyonu & psigmf & 0,14197 \\
\hline
\end{tabular}

Değerlendirme sonucu çan şekilli üyelik fonksiyonu (gbellmf), gauss üyelik fonksiyonu (gaussmf), 2.tip gauss üyelik fonksiyonu (gauss $2 \mathrm{mf}$ ) en az hata değerine sahip fonksiyon tipleri olarak belirlenmiştir. Hangisinin seçileceğinin belirlenmesi için eğitilen ağa ait çıktılar, gerçek verilerle karşılaştırılmış, en az hata değerini veren gauss $2 \mathrm{mf}$ seçilecek üyelik fonksiyonu olarak belirlenmiştir. Son olarak optimizasyon modeli olarak hybrid, çevrim eğitim sayısı olarak 50 seçilmiş ve istenilen hata toleransı 0 olarak belirlenmiştir.

Şekil 5 'te eğitilmiş setin kendi çıktıları ile gerçek çıktılarının karşılaştırılmasını görmek mümkündür. 


\section{O. DOĞAN}

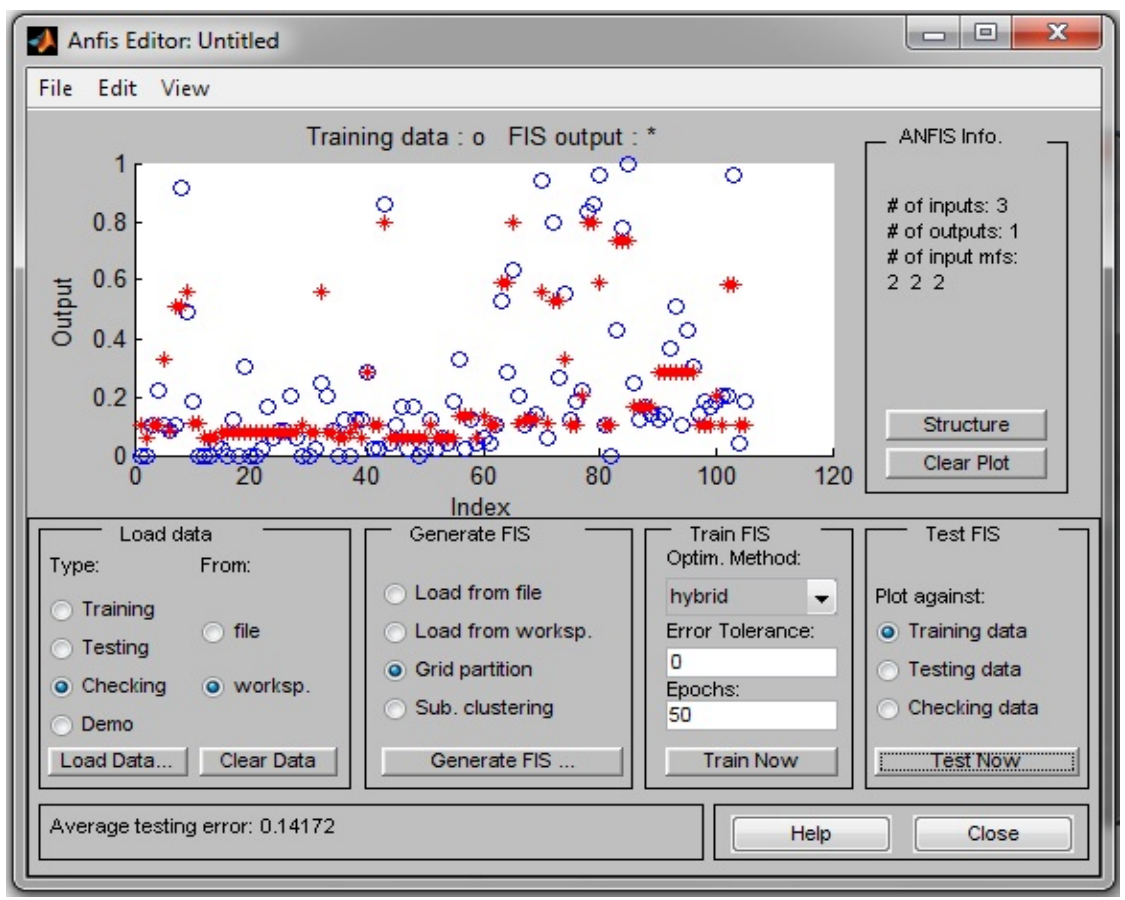

Şekil 5. Eğitim Setinde Gerçek Çıktı ve Tahmini Çıktıların Kıyaslanması

$\mathrm{Bu}$ aşamada, test verileri ile kurulan modelin etkinliği ölçülecektir. Modelden edinilen tahminler ile gerçek çıktı değerleri karşılaştırılmıştır. Yıldız ile gösterilen veriler ANFIS modelinin test girdileri kullanarak tahminlediği değerleri gösterirken, artı işareti ile gösterilen veriler, gerçek çıktı değerleridir (Şekil 6). Gerçek veriler ile bulanık ağın tahmin ettiği veriler benzerlik göstermektedir. RMSE değeri 0,10912 olarak bulunmuştur. 
Dokuz Eylül Üniversitesi İktisadi ve İdari Bilimler Fakültesi Dergisi Cilt:31, Sayl:1, Yll:2016, ss. 257-288

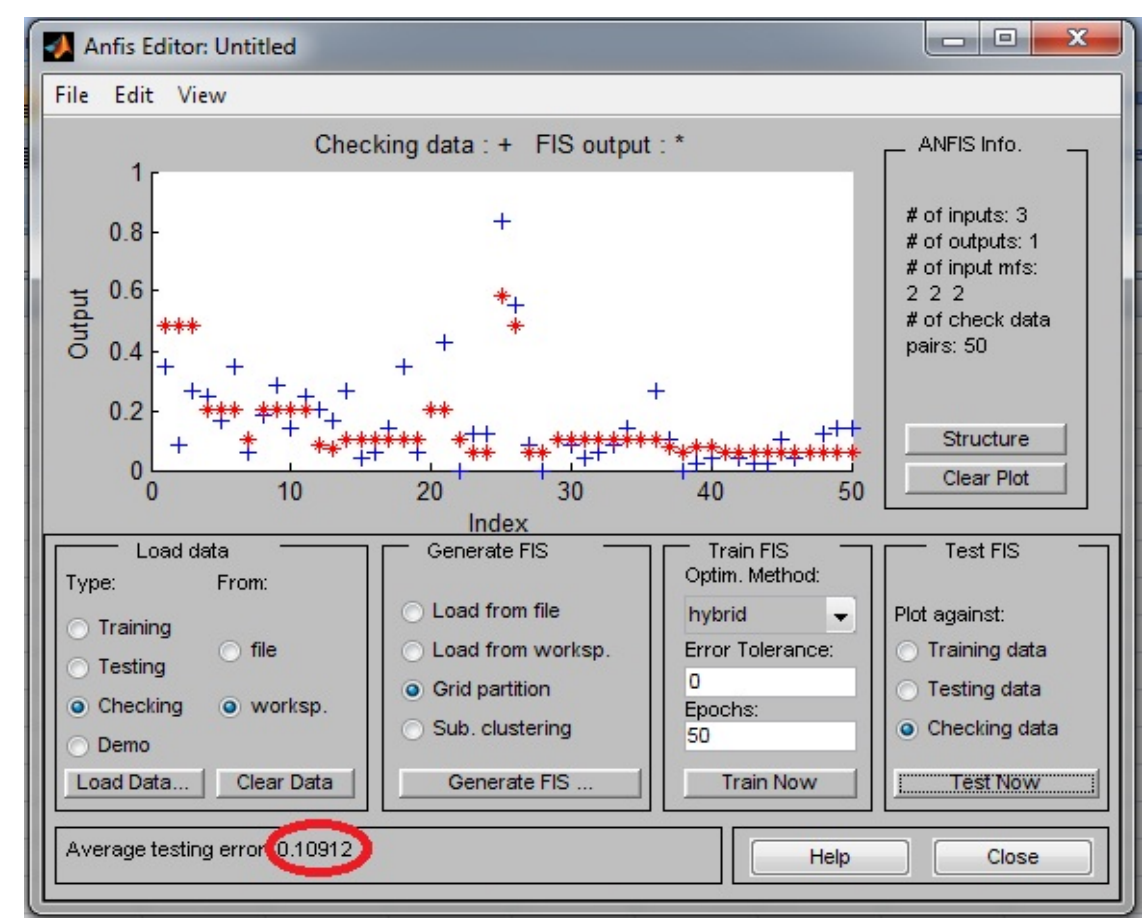

Şekil 6. Tahmin Çıktıları İle Gerçek Çıktıların Kıyas Grafiği

Üç girdi, bir çıktı değişkeni içeren, her girdi değeri için iki dilsel değişken (düşük ve yüksek) atanmış ve 8 kural $\left(2^{3}\right)$ içeren modelin ağ yapısı oluşturulmuştur. Çıktılara ait dilsel değişkenler, 8 adet kural çıktısına çok çok düşük ifadesi ile çok çok yüksek ifadesi aralığında dilsel ifadeler verilmesi ile oluşturulmuştur. Bu ifadeler; çok çok düşük, çok düşük, düşük, ortalama altı, ortalama üstü, yüksek, çok yüksek ve çok çok yüksek olarak tanımlanmıştır.

Kurulan modelden, atanan dilsel değişkenlere göre eğer-ve-ise kuralları çıkarmak mümkündür. Buna göre oluşturulan 8 kural Tablo 5 'te gösterildiği gibidir. 


\section{O. DOĞAN}

Tablo 5. Modelden Elde Edilen Kurallar

\begin{tabular}{|l|l|}
\hline No & Kural \\
\hline 1 & $\begin{array}{l}\text { Familya Fiyat düşük VE Selpak Fiyat düşük VE Selpak Maliyet düşük } \\
\text { İSE Talep çok çok düşük }\end{array}$ \\
\hline 2 & $\begin{array}{l}\text { Familya Fiyat düşük VE Selpak Fiyat düşük VE Selpak Maliyet düşük } \\
\text { İSE Talep çok düşük }\end{array}$ \\
\hline 3 & $\begin{array}{l}\text { Familya Fiyat düşük VE Selpak Fiyat yüksek VE Selpak Maliyet düşük } \\
\text { İSE Talep düşük }\end{array}$ \\
\hline 4 & $\begin{array}{l}\text { Familya Fiyat düşük VE Selpak Fiyat yüksek VE Selpak Maliyet düşük } \\
\text { İSE Talep ortalama altı }\end{array}$ \\
\hline 5 & $\begin{array}{l}\text { Familya Fiyat yüksek VE Selpak Fiyat düşük VE Selpak Maliyet düşük } \\
\text { İSE Talep çok çok yüksek }\end{array}$ \\
\hline 6 & $\begin{array}{l}\text { Familya Fiyat yüksek VE Selpak Fiyat düşük VE Selpak Maliyet düşük } \\
\text { İSE Talep çok yüksek }\end{array}$ \\
\hline 7 & $\begin{array}{l}\text { Familya Fiyat yüksek VE Selpak Fiyat yüksek VE Selpak Maliyet düşük } \\
\text { İSE Talep yüksek }\end{array}$ \\
\hline 8 & $\begin{array}{l}\text { Familya Fiyat yüksek VE Selpak Fiyat yüksek VE Selpak Maliyet düşük } \\
\text { İSE Talep ortalama üstü }\end{array}$ \\
\hline
\end{tabular}

Bulunan kurallar incelenecek olursa örneğin; 1. kurala göre Familya fiyat, Selpak fiyat ve Selpak maliyet değerlerinin tamamı düşük iken, talep değeri en alt seviyede (çok çok düşük) bulunmuştur. Familya fiyatının, Selpak fiyatından daha düşük olduğu düşünülürse alıcıların Familya fiyatına yöneldiği yorumu yapılabilir. 5. Kurala göre Familya fiyat yüksek iken, Selpak fiyat ve maliyeti düşük iken talep değeri en yüksek seviyededir. Diğer kurallar benzer biçimde yorumlanabilir. Ayrıca kullanıcı tarafindan uygun bulunmayan kurallar silinebilir, yeni kural 
eklenebilir ve mevcut kurallar değiş̧tirilebilir. $\mathrm{Bu}$ tip kurallar üzerindeki işlemlerden sonra ağ tekrar eğitilebilir

Veri hazırlama aşamasında belirtildiği gibi model hem zaman sıralı hem de 3 ve 4 girdili olarak sınanmıştır. Her modelin eğitim ve test hata değerleri için verilen RMSE değeri Tablo 6'daki gibidir.

Tablo 6. Modellerin Performans Değerleri

\begin{tabular}{|c|l|c|c|}
\hline Model No & Yöntem & Ĕ̆itim & Test \\
\hline 1 & $\begin{array}{l}\text { Dört girdili zaman sıralı veri } \\
\text { modeli }\end{array}$ & 0,0892 & 1,2189 \\
\hline 2 & $\begin{array}{l}\text { Dört girdili rastsal eğitim-test } \\
\text { veri modeli }\end{array}$ & 0,0900 & 0,34565 \\
\hline 3 & $\begin{array}{l}\text { Üç girdili zaman sıralı veri } \\
\text { modeli }\end{array}$ & 0,1041 & 1,2749 \\
\hline 4 & $\begin{array}{l}\text { Üç girdili rastsal eğitim-test veri } \\
\text { modeli }\end{array}$ & 0,1417 & 0,10912 \\
\hline
\end{tabular}

4 girdili modeller eğitim verileri için daha düşük hata değerleri vermiş olsa da bu durum ağın veri setini ezberlemesi dolayısıyla yaşanabilen bir durumdur. $\mathrm{Bu}$ nedenle eğitilen ağ mutlaka yeni veri seti ile test edilmelidir. Yeni veri ile test edilen modellere ait performans değerleri modelin etkinliği konusunda eğitim veri setine ait değerlere kıyasla daha belirleyicidir. Test sonuçları karşılaştırıldığında en küçük hataya sahip $(0,10912)$ test sonucunu veren üç girdi ve rastsal veri seçiminin yapıldığı model, diğer durumlardan daha iyi sonuç vermiştir. Ayrıca girdi sayısındaki azalmanın ANFIS modeline olumlu etki yaptığı açıkça görülmektedir. Bu durum Jang (1993)'ın bulguları ile uyuşmaktadır. 


\section{O. DOĞAN}

\subsection{ANFIS Modeli Sonuçlarının Gerçek Veriler ile Karşılaştırılması}

ANFIS veri alanına yüklenmiş ve eğitilmiş verilerle oluşturulmuş modelin etkinliğini, modelin geçmiş verilerde nasıl sonuç vereceği ile gerçek verilerin karşılaştırılması yoluyla ölçmek mümkündür.

Modelin geçmiş eğitim ve test veri kümesine yönelik çıktılarını ortaya koymak için Matlab programında evalfis komutu kullanılabilir (Yücel, 2010: 94). Bunun için Matlab çalışma alanına çalışmada kullanılan 155 adet verinin yalnızca girdileri yüklenmiştir.

Modelden elde edilen çıktılar ile gerçek veriler arasındaki ilişkinin ortaya konulması için 155 veriden oluşan gerçek çıktı değerleri ile modelden elde edilen çıktılar, SPSS paket programına yüklenmiş, İlişkili Örneklem t Testi kullanılmıştır. Bu testin çıktıları Tablo 7 ve Tablo 8'de gösterildiği gibidir.

Tablo 7. Gerçek Çıktılar ile Model Çıktıları Karşılaştırması (a)

\begin{tabular}{|l|r|r|r|r|c|}
\hline & Ortalama & $\mathrm{N}$ & Std. Sapma & $\mathrm{R}$ & $\mathrm{p}$ \\
\hline Gerçek Çıktılar &, 1933 & 155 &, 23092 &, 819 & \multirow{2}{*}{, 000} \\
\cline { 1 - 4 } &, 1902 & 155 &, 19436 & & \\
\hline
\end{tabular}

Gerçek çıktılar ile model çıktıları arasında $\alpha=0,05$ düzeyinde anlamlı bir ilişki $\operatorname{vardır}(p<0,05)$. $R$ değeri 0,819 olarak bulunmuştur. Bu değer, veriler arası ilişkinin yüksek düzeyde ve pozitif yönlü olduğunu göstermektedir.

Tablo 8. Gerçek Çıktılar ile Model Çıktıları Karşılaştırması (b)

\begin{tabular}{|l|l|l|l|l|}
\hline & \multicolumn{1}{|c|}{$\begin{array}{c}\text { Farkların } \\
\text { Ortalaması }\end{array}$} & Std. Sapma & $\mathrm{t}$ & $\mathrm{p}$ \\
\hline $\begin{array}{l}\text { Gerçek Çıktılar - ANFIS } \\
\text { Çıktıları }\end{array}$ & 0,00306 & 0,13248 & 0,288 & 0,774 \\
\hline
\end{tabular}


Tablo 8 gerçek çıktılar ile model çıktıları arasındaki farkları, t test değerini, serbestlik derecesini ve $\mathrm{p}$ değerlerini göstermektedir. Buna göre iki veri kümesi için $\mathrm{p}=0,774>\alpha=0,05$ olduğundan çıktı değerleri arasında fark yoktur yorumu yapılabilir. Buna göre kurulan model, çıtı değerlerini tahmin etmede oldukça başarılıdır.

Kurulan modelin tahmin yapılması için kullanılabilmesi, girdi değerleri modele verilerek çıktı değerlerini hesaplanması istenirse yeni veri kümesi girilerek modelden çıktı alınması sağlanabilir.

\section{SONUÇLAR VE ÖNERİLER}

Talebi doğru tahmin etmek ve edinilen bilgiler doğrultusunda kararlar almak işletmenin bütün fonksiyonları için kritik bir unsurdur.

Bulanık Mantık Yöntemi dilsel ifadeleri modele dâhil edebilmesi veya modelden kullanılabilir ve kolay anlaşılabilir dilsel ifadeler çıkarımı yaparak ortaya koyabilme kolaylığı açısından veri kümelerinden kullanılabilir bilgi edinmek amacıyla sıklıkla kullanılan yöntemlerden birisidir. Bunun yanı sıra gelişen bilgisayar teknolojisi; veriler arası ilişkilerin makine öğrenmesi yoluyla bilgisayarlara öğretilebilmesini olanaklı kılmıştır. Yapay sinir ağları algoritmaları bu amaçla yine araştırmacılar ve karar vericiler tarafından tercih edilen yöntemlerdir. Veri madenciliği uygulamalarının en önemli yapı taşlarından olan yapay sinir ağları ve bulanık mantık modelleri birbirlerinin tamamlayıcı yapılar olmaları nedeniyle son yıllarda birçok alanda birlikte kullanılmaktadır.

$\mathrm{Bu}$ çalışma kapsamında, işletmelerin talep tahmini problemine yapay sinir ağları ve bulanık mantık yapay sinir ağları entegre modelleri ile çözüm aranmıştır. Çalışmanın öncelikli amacı bulanık mantık ve yapay sinir ağlarının birlikte kullanıldığı bir yapının talep tahmininde ne derece etkili olduğunu göstermektir. ANFIS modelini kullanabilmek için veri kümesinin yapısının modellere öğretilmesi gerekmektedir. Eğitim veri seti olarak adlandırılan bu veri seti, modellerin etkinliklerinin test edilmesi için kullanılan test setinden farkl1lıklar gösteriyor ise bu modellerin etkin sonuçlar veremeyeceği açıtır. Rastsal eğitim 


\section{O. DOĞAN}

seti ile öğrenme yaptırılan modeller ele alındığında ANFIS modelinin daha az girdi ile daha etkin sonuç verdiği tespit edilmiştir. Modelin hazırlanması için yapay sinir ağları ve ANFIS metotları geleneksel metotlara göre daha az zaman gerektirmektedir. Çünkü bu metotlar, veriler arası ilişkinin tanımlanmasını, bir fonksiyonun ortaya konmasını gerektirmezler. Veriler arasındaki ilişkiyi eğitim veri kümesi vasıtasıyla kendileri öğrenirler.

Yapay sinir ağlarının bulanık mantık ile beraber kullanılması dilsel değişkenlerin modele dâhil edilebilmesi konusunda karar vericiye fayda sağlamaktadır. $\mathrm{Bu}$ çalışmada girdi değişkenleri için bir dilsel değişken tanımlanmamıştır. Ancak bundan sonraki çalışmalarda bu şekilde bir model denenebilir. Birçok farklı dilsel değişkeni veri kümesine dâhil etmek mümkündür. Örneğin veri kümesinde bir mevsimsel etkiye rastlanması durumunda bu mevsimsellik sayısal olarak modele dâhil edilebilir.

Çalışmada girdi değişkenleri ve çıktı değeri, yüksek ve düşük olmak üzere iki dilsel değişken ile derecelendirilmiştir. Bu ANFIS yapısının getirdiği avantajlardan biridir. Karar verici isterse girdi ve çıktı değişkenlerinin değerlerini ikiden fazla dilsel değişken ile derecelendirebilir. Kurulan model bu derecelendirmeler yardımı ile veri kümesi içinden anlamlı kurallar türetmektedir. $\mathrm{Bu}$ şekilde dilsel değişkenlerdeki artış, modelin ortaya koyduğu kurallarda da artış anlamına gelir. Çalışmanın uygulama kısmında model tarafından üretilen kurallar belirtilmiştir, bu kuralların tamamı anlamlıdır. Bulanık mantık ve yapay sinir ağları ile yapılan veri madenciliği uygulamaları her ne kadar iyi sonuçlar verse de son analiz aşamasında insan kontrolünü gerekli kılmaktadır. ANFIS uygulamasının yapıldığı program; kural değişimine, tanımlanmış kuralın silinmesine ya da yeni kural eklenmesine olanak vermektedir. Ayrıca değişkenler arası ilişkinin grafiksel olarak ifade edilmesi de mümkündür.

Talep tahmini problemleri genellikle doğrusal olmayan yapıdadırlar. Bu nedenle modellenmesi oldukça güçtür. Doğrusal olmayan yapılarda yapay sinir ağları ve bulanık mantık metotları daha etkin sonuçlar verecektir. 
Bütün avantajlı yanları ve gelişmeye devam eden yapılarına rağmen yapay sinir ağları ve ANFIS metotlarının handikaplı olduğu noktalar da söz konusudur. Bu metotlarda belirli veri kümesi yapılarına uygun modellerden yaratılır, genel geçer her veri kümesine uygun modeller çok rastlanır değildir. Ayrıca eldeki veri seti için uygun modelin ortaya çıkarılması esnasında birçok deneme yapılmalıdır. Veriler için örneklemin seçimi, hangi öğrenme metodunun kullanılacağı, veri kümesinin büyüklüğü, kullanılacak üyelik fonksiyonunun tipi çıktı değerlerinin kalitesini belirleyici hususlardır ve bu değerler denemeler ile belirlenir.

Sonuç olarak, bu çalışma kapsamında talep tahmini problemine yapay sinir ağları ve bulanık mantık entegre modeli ile çözüm aranmıştır. Belirtilen öneriler ile birlikte bu metodun daha etkin sonuçlar vereceği ve daha geniş bir kullanım alanı bulacağı umulmaktadır.

\section{KAYNAKÇA}

ABURTO, L., WEBER, R. (2007), "Improved Supply Chain Management Based on Hybrid Demand Forecasts", Applied Soft Computing, 7, 136-144.

ALPAYDIN, E. (2011), Yapay Öğrenme, Boğaziçi Üniversitesi Yayınevi, İstanbul.

ALTUNÖZ, U. (2013), "Bankaların Finansal Başarısızlıklarının Yapay Sinir Ağları Modeli Çerçevesinde Tahmin Edilebilirliği”, Dokuz Eylül Üniversitesi Iktisadi ve İdari Bilimler Fakültesi Dergisi, 28(2), 189-217.

AMSTRONG, J. S., GREEN, K. C. (2011), "Demand Forecasting: Evidence-Based Methods", Oxford Handbook in Managerial Economics, (Ed. C. R. Thomas, W. F. Shughart), Oxford University Press.

ANSUJ, A. P., CAMARGO, M. E., RADHARAMANAN, R., PETRY, D.G., (1996), "Sales Forecasting Using Time Series And Neural Networks", Computers And Industrial Engineering, 31(1), 421-424.

AZADEH, A., SABERI, M., NADIMI, V., IMAN M., BEHROOZNIA, A. (2010), "An Integrated Intelligent Neuro-Fuzzy Algorithm For Long-Term Electricity Consumption: Cases Of Selected EU Countries", Acta Polytechnica Hungarica, 7(4), 71-90.

BABUSKA, R. (2001), Fuzzy And Neural Control (Lecture Notes), Delft: Delft University of Technology, ftp://ftp.unicauca.edu.co/Facultades/FIET/ 


\section{O. DOĞAN}

DEIC/Materias/Control\%20Inteligente/Parte\%20I/clase\%2003\%20int/clase1_Babu ska.pdf, (20.10.2012).

BALA, P. K. (2012), "Improving Inventory Performance with Clustering Based Demand Forecasts", Journal of Modelling in Management, 7(1).

BAYKAL, N., BEYAN, T. (2004a), Bulanık Mantık Ilke Ve Temelleri, Bıçaklar Kitabevi, Ankara.

BAYKAL, N., BEYAN, T. (2004b), Bulanık Mantık, Uzman Sistem Denetleyiciler, Bıçaklar Kitabevi, Ankara.

BOX, G. E., JENKINS, G. M., REINSEL, G. C. (2008), Time Series Analysis Forecasting Control Fourth Edition, John Willey\&Sons Inc., New Jersey.

CASE, K. E., FAIR R. C. (1999), Principles of Mikroeconomica, Prenhall Inc., New Jersey.

CHIN, K., ARTHUR, R. (1996), "Neural Network vs. Conventional Methods of Forecasting", Journal of Bussines Forecasting, 14(4), 17-22.

DEMİ, H., GÜMÜŞOĞLU, Ş. (2009), Üretim Isşlemler Yönetimi, Beta Basım Yayım Dağıtım A.Ş., İstanbul.

DENTON, J. W. (1995), "How Good Are Neural Networks For Casual Forecasting?", The Journal of Business Forecasting Methods \& Systems, 14(17).

EFENDİGIL, T., ÖNÜT, S., KAHRAMAN, C. (2009), “A Decision Support System for Demand Forecasting with Artificial Neural Network and Neuro-Fuzyy Models: A Comparative Analysis", Expert Systems with Applications, 36(3), 66976707.

EFENDİGIL, T. (2008), Müşteri Odaklı Sistemler İçin YSA ve Bulanık Çıkarım Tabanlı Karar Destek Sistemi Yaklaşımı, Yıldız Teknik Üniversitesi Fen Bilimleri Enstitüsü, Doktora Tezi, İstanbul.

ELMAS, Ç. (2011), Yapay Zeka Uygulamaları (Yapay Sinir Ağlart-Bulanık Mantık-Genetik Algoritma, (2. Baskı), Seçkin Yayıncılık, Ankara.

GALINDO, J., URRUTIA, A., PIATTINI, M. (2005), Fuzzy Database: Modelling Design and Implemantation, Idea Group Publishing, Londra.

HEIZER, J., RENDER, B. (2001), Operations Management, Prentice Hall, New Jersey. 
HOSHMAND, A. R. (2010), Business Forecasting, Second Edition: A Practical Approach, Routledge, Newyork.

JAIN, C. L., MALEHORN, J. (2005), Practical Guide To Business Forecasting, Graceway Publishing Company Inc., New York.

JANG, J.-S. R. (1993), “ANFIS: Adaptive-Network-Based Fuzzy Inference System”, Ieee Transactions on Systems, Man and Cybernetics, 23(3), 665-685.

KARAHAN, M., (2011), İstatistiksel Tahmin Yöntemleri: Yapay Sinir Ağları Metodu İle Ürün Talep Tahmini Uygulaması, Selçuk Üniversitesi Sosyal Bilimler Enstitüsü, Doktora Tezi, Konya.

KHASEI, M., BIJARI M., (2010), “An Artificial Neural Network (P,D,Q) Model For Timeseries Forecasting”, Expert Systems With Applications, 37(1), 479-489.

KONAR, A. (2000), Artificial Intelligence And Soft Computing-Behavioral and Cognitive Modeling, Crc Press Llc, Boca Raton, Florida.

KRAEMER K. L., LESLIE, K. J. (1988), "Computer-Based Systems For Cooperative Work And; Group Decision Making”, Acm Computer Surveys, 20(2), 115-146.

LACHTERMACHER, G., FULLER, J. D. (1995), "Backpropagation in TimeSeries Forecasting", Journal of Forecasting, 14, 381-393.

LEE, K. H. (2005), First Course On Fuzzy Theory and Applications, Springer, Berlin.

MAIER, H. R., DANDY, G. C. (1996), "Neural Network Models For Forecasting Univariate Time Series", Neural Networks World, 6(5), 747-772.

MARAKAS, M. G. (2003), Decision Support Systems in The 21st Century, Prentice Hall, New Jersey.

MATHWORKS. (2002), Fuzzy Logic Toolbax for Use with Matlab, Mathworks Inc., Natick, Massachusetts.

MITCHELL, T. M. (1997), Machine Learning, Mcgraw-Hill Science.

ÖZDEMIR, A. (2010), Yönetim Biliminde Ileri Araştırma Yöntemleri ve Uygulamalar, Beta Basım Yayım Dağıtım, İstanbul.

ÖZTEMEL, E. (2012), Yapay Sinir Ağları, Papatya Yayınc1lı, İstanbul. 


\section{O. DOĞAN}

PASSINO, K. M., YURKOVICH, S. (1998), Fuzzy Control, Addison Wesley Longman, Inc., California.

SPSS. (2007), SPSS Trends 16.0, SPSS Inc., Chicago.

SRINIVASAN, D., LIEW, A. C., CHANG, C. S. (1994), "A Neural Network Short-Term Load Forecaster”, Electric Power Systems Research, 28, 227-234.

ŞEN, Z. (2004), Mühendislikte Bulanık Mantık (Fuzzy) Ile Modelleme Prensipleri, Su Vakfi Yayınları, İstanbul.

TEKIN, M., (1996), Üretim Yönetimi, Arı Ofset Matbaacılık, Konya.

ThOMASSEY, S., HAPPIETTE, M., CASTELAIN, J. M. (2003), "A Short And Mean-Term Automatic Forecasting System-Application to Textile Logistics", European Journal of Operational Research, 161, 275-284.

TSENG, F.-M., CHENG, H. Y., HSIUNG, G. (2002), "Combining Neural Network Model With Seasonal Time Series Arıma Model", Technological Forecasting and Social Change, 69, 71-87.

WANG F.-K., CHANG, K.-K., TZENG, C.-W. (2011), "Using Adaptive NetworkBased Fuzzy İnference System To Forecast Automobile Sales", Expert Systems with Applications, 38, 10587-10593.

WITTEN, I. H., FRANK, E., HALL, M. A. (2011), Data Mining: Practical Machine Learning Tools And Techniques, Elsevier Inc., Burlington, USA.

YÜCEL, A. (2010), Tedarikçi Seçimi Probleminde Bütünleşik Sinirsel Bulanık Mantık Yaklaşımı, İstanbul Üniversitesi Endüstri Mühendisliği Bölümü, Doktora Tezi, İstanbul.

YÜKSEL, H. (2008), Üretim/İşlemler Yönetimi, Nobel Yayın Dağıtım, Ankara.

ZADEH, L. A. (1988), Fuzzy Logic, University of California, Software Engineers, Berkeley.

ZADEH, L. A. (1965), "Fuzzy Sets", Information And Control, 8, 338-353.

ZHANG, G., PATUWO, B. E., HU, M. Y. (1998), Forecasting With Artificial Neural Networks: The State Of The Art", International Journal of Forecasting, 14, $35-62$. 